Article

\title{
The In Vivo Quantitative Assessment of the Effectiveness of Low-Dose Photodynamic Therapy on Wound Healing Using Optical Coherence Tomography
}

\author{
Hala Zuhayri D, Viktor V. Nikolaev (D), Tatiana B. Lepekhina, Ekaterina A. Sandykova, Natalya A. Krivova \\ and Yury V. Kistenev *(D) \\ Laboratory of Laser Molecular Imaging and Machine Learning, Tomsk State University, Lenin Ave. 36 , \\ 634050 Tomsk, Russia; zuhayri.n.hala@gmail.com (H.Z.); vik-nikol@bk.ru (V.V.N.); \\ tatiana_lepekhina@mail.ru (T.B.L.); katrin_nemchenko@mail.ru (E.A.S.); nakri@res.tsu.ru (N.A.K.) \\ * Correspondence: yuk@iao.ru
}

check for updates

Citation: Zuhayri, H.; Nikolaev, V.V.; Lepekhina, T.B.; Sandykova, E.A.; Krivova, N.A.; Kistenev, Y.V. The In Vivo Quantitative Assessment of the Effectiveness of Low-Dose Photodynamic Therapy on Wound Healing Using Optical Coherence Tomography. Pharmaceutics 2022, 14, 399. https://doi.org/10.3390/ pharmaceutics14020399

Academic Editors: Udo Bakowsky, Matthias Wojcik, Eduard Preis and Gerhard Litscher

Received: 18 December 2021

Accepted: 9 February 2022

Published: 11 February 2022

Publisher's Note: MDPI stays neutral with regard to jurisdictional claims in published maps and institutional affiliations.

Copyright: () 2022 by the authors Licensee MDPI, Basel, Switzerland. This article is an open access article distributed under the terms and conditions of the Creative Commons Attribution (CC BY) license (https:/ / creativecommons.org/licenses/by/ $4.0 /)$.

\begin{abstract}
The effect of low-dose photodynamic therapy on in vivo wound healing was investigated using optical coherence tomography. This work aims to develop an approach to quantitative assessment of the wound's state during wound healing including the effect of low-dose photodynamic therapy using topical application of two different photosensitizers, 5-aminolevulinic acid and methylene blue, and two laser doses of $1 \mathrm{~J} / \mathrm{cm}^{2}$ and $4 \mathrm{~J} / \mathrm{cm}^{2}$. It was concluded that the laser dose of $4 \mathrm{~J} / \mathrm{cm}^{2}$ was better compared to $1 \mathrm{~J} / \mathrm{cm}^{2}$ and allowed the wound healing process to accelerate.
\end{abstract}

Keywords: low dose photodynamic therapy; wound healing; 5-aminolevulinic acid; methylene blue; optical coherence tomography

\section{Introduction}

According to the World Health Organization (WHO), burn wounds result in approximately 180,000 deaths every year and nearly 11 million injuries that require medical treatment worldwide [1]. Cutaneous wounds are widespread and differentiated into acute and chronic wounds [2].

Wound healing is a complex physiological process at the cellular and molecular levels including the extracellular matrix synthesis, the replacement of type III collagen with type I collagen, and scar tissue formation [3-6]. These processes are divided into four overlapping stages: coagulation (hemostasis), inflammation, proliferation, and remodeling [7,8]. Some underlying diseases affect the wound healing process including peripheral arterial and venous disease or diabetes; acute wounds may have impaired healing, which can lead to a chronic stage [9-11]. In developed countries, 1-6\% of the population suffers from chronic wounds [12-14].

It is known that a low dose photo process with photoactive compounds promotes the healing of skin diseases and leads to results in rejuvenation and wound healing $[15,16]$. Low-dose photodynamic therapy (LDPDT) is widely used to treat skin diseases and wound healing where it reduces the treatment time, accelerates tissue repair, and promotes healing $[17,18]$. The method is based on using a photosensitizer (PS), which accumulates in tissues, followed by irradiation of the tissue with a light source with an appropriate wavelength. The latter causes the formation of reactive oxygen species (ROS) [19,20]. Low concentrations of ROS can trigger cell repair processes including proliferation and offer promising treatments to accelerate healing. Different PSs have been studied in the wound healing process, which has a relevant role in ensuring PDT effectiveness in skin wound healing [21] such as 5-aminolevulinic acid (5-ALA) and methylene blue (MB) [22-25]. MB is a popular PS among the phenothiazinium derivatives that have attracted the attention of different research groups working and achieving good results in wound healing [25-27]. 
Recently, MB was shown to have an antioxidant role [28]. Additionally, 5-ALA is among the most effective photosensitizers and is widely used to present a better achievement concerning wound healing $[17,22,29]$.

The Arndt-Schultz Law is an appropriate model to demonstrate that low levels of light have a better effect in wound healing than higher levels, which may have an inhibitory or cytotoxic effect $[30,31]$. Hawkins and Abrahamse studied the behavior in vitro of human skin fibroblasts using different irradiation doses of $0.5,2.5,5,10$, and $16 \mathrm{~J} / \mathrm{cm}^{2}$. They demonstrated that higher laser doses $\left(10\right.$ and $\left.16 \mathrm{~J} / \mathrm{cm}^{2}\right)$ resulted in increased cellular damage as well as decreased cell viability and proliferation [32]. Results for different energy doses were described for $4 \mathrm{~J} / \mathrm{cm}^{2}$ [33] and for $1 \mathrm{~J} / \mathrm{cm}^{2}$ and $2 \mathrm{~J} / \mathrm{cm}^{2}$ [34]. Basso et al. demonstrated that irradiation of cultured human gingival fibroblasts with energy doses of 0.5 and $3 \mathrm{~J} / \mathrm{cm}^{2}$ resulted in a significant increase in cellular metabolism compared with the non-irradiated control group and the cells irradiated with higher energy doses of 5 and $7 \mathrm{~J} / \mathrm{cm}^{2}$ [35]. The most significant biological effects were seen with predominant dose values (i.e., up to $5 \mathrm{~J} / \mathrm{cm}^{2}$ ), which were within the Arndt-Schultz curve [36].

Traditionally, wounds have been observed invasively with a histochemical assessment of the biopsies [3,8]. Visual observation is a common tool for wound assessment. Additionally, clinical wound evaluation is a widely used and the least expensive method of assessing wound depth. This method relies on a subjective evaluation of the external features of the wound such as wound appearance, capillary refill, and burn wound sensibility to touch and pinprick, providing diagnostic accuracy at the level of 60-75\% [37]. These methods are not quantitative and can lead to additional tissue damage and impair healing. Accordingly, the development of noninvasive and accurate methods of wound analysis is relevant.

Optical coherence tomography (OCT) is a noninvasive 3D imaging method of biological tissues with a spatial resolution of $5-10 \mu \mathrm{m}$ and a penetration depth of $1-2 \mathrm{~mm}[38,39]$. Epidermal thickness is a critical parameter for assessing epithelialization during wound healing $[40,41]$.

OCT could detect essential morphological changes during wound healing (e.g., epidermis, dermis, adipose tissue, and granulation) that was based primarily on their backscattering characteristics [42-44]. The use of polarization-sensitive OCT revealed higher birefringence in scars compared to healthy skin [45]. OCT-based angiography provides in vivo, three-dimensional vascular information by using flowing red blood cells as intrinsic contrast agents, allowing visualization of functional vessel networks within microcirculatory tissue beds non-invasively, without needing dye injection [46].

This work aims to develop a method for quantitative in vivo evaluation of wounds using OCT during the wound healing process including a quantitative assessment of the effect of LDPDT using the topical application of two different photosensitizers (5-ALA and $\mathrm{MB}$ ) and two laser doses of $1 \mathrm{~J} / \mathrm{cm}^{2}$ and $4 \mathrm{~J} / \mathrm{cm}^{2}$.

\section{Materials and Methods}

\subsection{Wound Model Protocol}

This study used 15 male laboratory CD1 mice, weighing 25-30 g and aged 6-7 weeks, obtained from the Department of Experimental Biological Models of the Research Institute of Pharmacology, TSC SB RAMS. Before the experiment, the mice were kept seven days in the standard conditions of a conventional vivarium with free access to water and food, and a $12 / 12$ light regime, in a ventilated room at a temperature of $20 \pm 2{ }^{\circ} \mathrm{C}$ and a humidity of $60 \%$. The experimental protocol of this research was approved by the Bioethical Committee of Tomsk State University (Protocol No. 4, 10.02.2021), registration No. 6.

The mice were anesthetized by isoflurane using the Ugo Basile gas anesthesia system, where the mice were put in a glass chamber connected to isoflurane (Figure 1). The wound area was prepared through depilation using Veet cream (made in France), rinsed with saline solution, and sterilized using chlorhexidine $20 \%$. A full-thickness cutaneous wound (diameter $5 \mathrm{~mm}$ ) was formed by cutting out a whole layer skin flap with scissors on both of the hind paws of each animal under isoflurane anesthesia. The experiment was performed 
in a time-lapsed schedule for the wound aging on days 1,3, 7, and 14. Additionally, the day of wound formation was defined as day 0 .

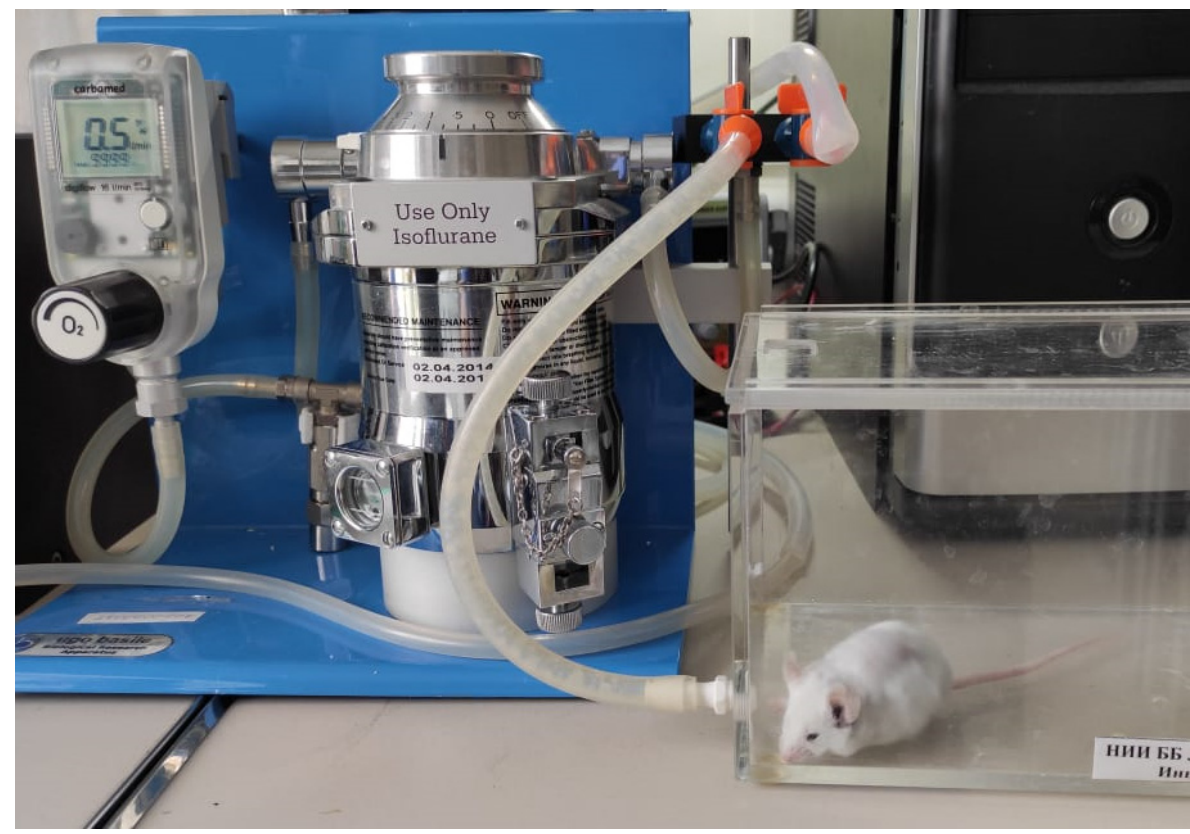

Figure 1. Anesthetized mice by isoflurane using the Ugo Basile gas anesthesia system.

\subsection{Low Dose Photodynamic Therapy Protocol}

Both of the photosensitizers 5-ALA $20 \%$ and MB $0.01 \%$ in saline solution were topically administered directly on the wound; after $30 \mathrm{~min}$, the irradiation was started by an AlGalnP laser $(\lambda=630 \mathrm{~nm}, \mathrm{P}=5 \mathrm{~mW})$ with two doses: $1 \mathrm{~J} / \mathrm{cm}^{2}$ and $4 \mathrm{~J} / \mathrm{cm}^{2}$, and the procedure was carried out under the influence of isoflurane. 5-ALA was applied on the wounds on the right hind paws, $\mathrm{MB}$ was applied on the left ones. The animals were divided according to the laser dose and photosensitizer into five groups: the control group, the LDPDT-5-ALA $1 \mathrm{~J} / \mathrm{cm}^{2}$, LDPDT-MB $1 \mathrm{~J} / \mathrm{cm}^{2}$, LDPDT-5-ALA $4 \mathrm{~J} / \mathrm{cm}^{2}$, and LDPDT-MB $4 \mathrm{~J} / \mathrm{cm}^{2}$. LDPDT procedure was repeated once immediately after wound formation.

\subsection{Optical Coherence Tomography Protocol}

The experiments were carried out using optical coherence tomography (OCT) on the GANYMEDE-II system (Thorlabs, USA) with the basic scanning module OCTG-900. It is possible to obtain information on the optical characteristics, morphology, and elastic properties of biological tissues using OCT. The GANYMEDE-II system uses a superluminescent diode with an operating wavelength of $930 \pm 50 \mathrm{~nm}$. The superluminescent diode allows one to reach a signal penetration depth up to $2.9 \mathrm{~mm}$ with an axial resolution of up to 6.0 microns (air/tissue). The width of the spectral band was $100 \mathrm{~nm}$. Figure 2 shows an example of placing a mouse on the substrate of OCT. As a result, B-scans were obtained-two-dimensional images. Data processing was carried out using ThorImageOCT 5.0.1., with the following parameters: size $2469 \times 675$ pixel, FOV $4.66 \times 1.94 \mathrm{~mm}$, and pixel size $1.89 \times 2.88 \mu \mathrm{m}$, with 20 frames. The experiment was repeated with a $30^{\circ}$ rotation around the previous position. 


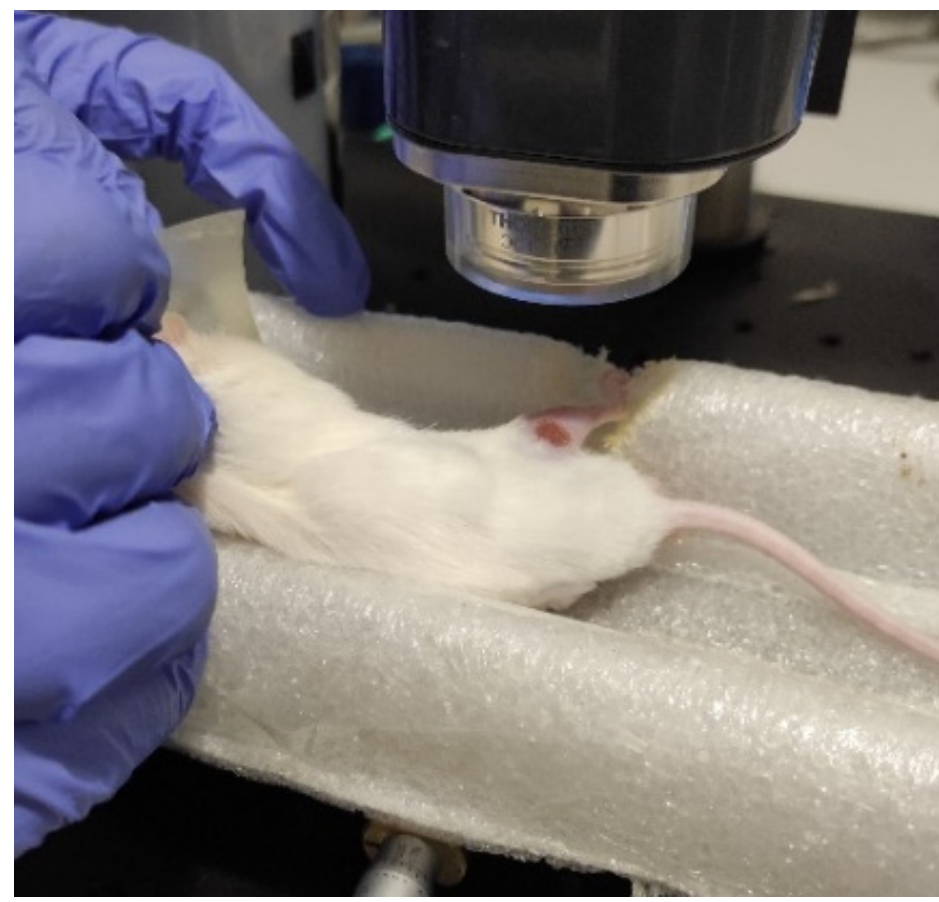

Figure 2. The mouse positioning during OCT imaging.

\subsection{Statistical Analysis}

The OCT data were exported using the ThorImageOCT 5.0.1 program to files. txt. Statistical analysis and data processing were carried out in Python 3.6 using libraries (numpy, scipy, matplotlib). All calculated parameters were expressed as the mean \pm standard deviation. The Pearson test was applied to assess the level of statistically significant differences among groups under study. Statistical power was used at 0.95 and 0.99 . The $p$-values were calculated for all groups on all days.

\section{Results}

\subsection{OCT Imaging}

Figure 3a shows a photo of healthy skin, and an OCT B-scan for the area, marked with a red arrow, is shown in Figure 3b. The B-scan data were normalized so that the stratum corneum, corresponding to the region with the highest pixel intensity, was located at the top of the image. After normalization, the signal intensity was calculated at different tissue depths from 0 to $0.8 \mathrm{~mm}$ (A-scan) and visualized as shown in Figure 4. The maximum intensity values were at a depth of 0 to $2-4 \mu \mathrm{m}$, which corresponded to the stratum corneum, and then the signal intensity gradually decreased to $\sim 20 \mu \mathrm{m}$, which corresponded to the epidermis. The dermis starts from $30-40 \mu \mathrm{m}$, which was accompanied by a decrease in intensity to the minimum values at a depth of $0.8 \mathrm{~mm}$.

Photos of the observation area and B-scans of the wound at different time points on days 1, 3, 7, and 14 for the control (without LDPDT) are shown in Figure 5.

The wound healed typically without pathologies, and the injury was close to healing on day 14. The difference in signal intensities at different stages of wound healing on different days is shown in Figure 6. On day 1 after the wound forming procedure, the signal had a low intensity, while the signal of the dermis started decreasing from $0.3 \mu \mathrm{m}$, so the signal from 0 to 0.3 corresponded to the formed wound scab. The signal intensity increased on days 3 and 7. On day 14, the signal intensity values were close to healthy skin.

OCT images for the LDPDT-5-ALA groups are shown for a laser dose of $1 \mathrm{~J} / \mathrm{cm}^{2}$ in Figure 7 and $4 \mathrm{~J} / \mathrm{cm}^{2}$ in Figure 8 . The intensity signal for LDPDT-5-ALA $4 \mathrm{~J} / \mathrm{cm}^{2}$ had the same behavior as the control. On day 1 for LDPDT-5-ALA $1 \mathrm{~J} / \mathrm{cm}^{2}$, the attenuation signal corresponding to the dermis started from $\sim 0.3 \mathrm{~mm}$. Similar to the control, the signal 
intensity increased on days 3 and 7, and on day 14, the signal intensity values were close to healthy skin, as shown in Figure 9a. In the same way for LDPDT-5-ALA $4 \mathrm{~J} / \mathrm{cm}^{2}$, the intensity signal started decreasing from $\sim 0.2 \mathrm{~mm}$ on day 1 . On days 3 and 7 , the signal intensity values increased to close to the value of healthy skin on day 14 more than the LDPDT-5-ALA $1 \mathrm{~J} / \mathrm{cm}^{2}$ group, as shown in Figure $9 \mathrm{~b}$.

Measurements were similarly carried out for the MB photosensitizer with two laser doses of $1 \mathrm{~J} / \mathrm{cm}^{2}$ (Figure 10) and $4 \mathrm{~J} / \mathrm{cm}^{2}$ (Figure 11). The intensity signal for LDPDT-MB on day 14 was close to the values for healthy skin for different exposure doses, as shown in Figure 12.

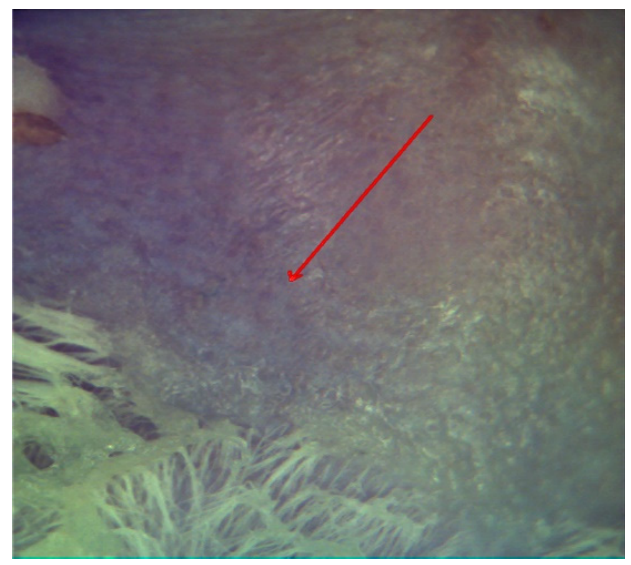

(a)

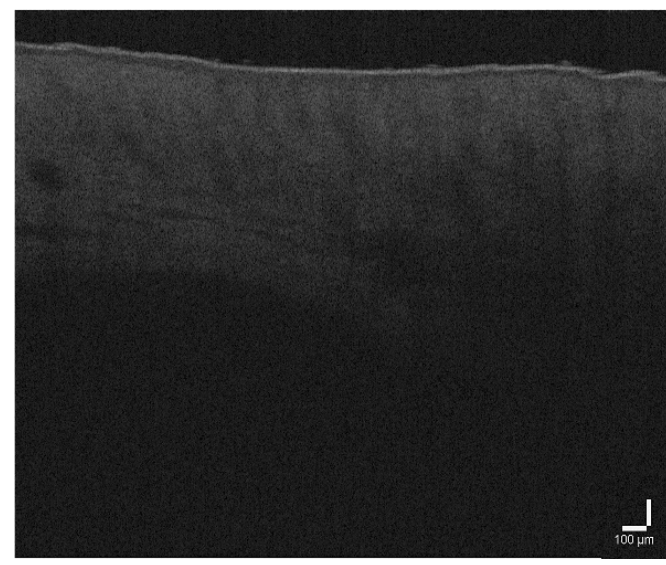

(b)

Figure 3. (a) Visual observation for healthy skin, (b) OCT imaging.

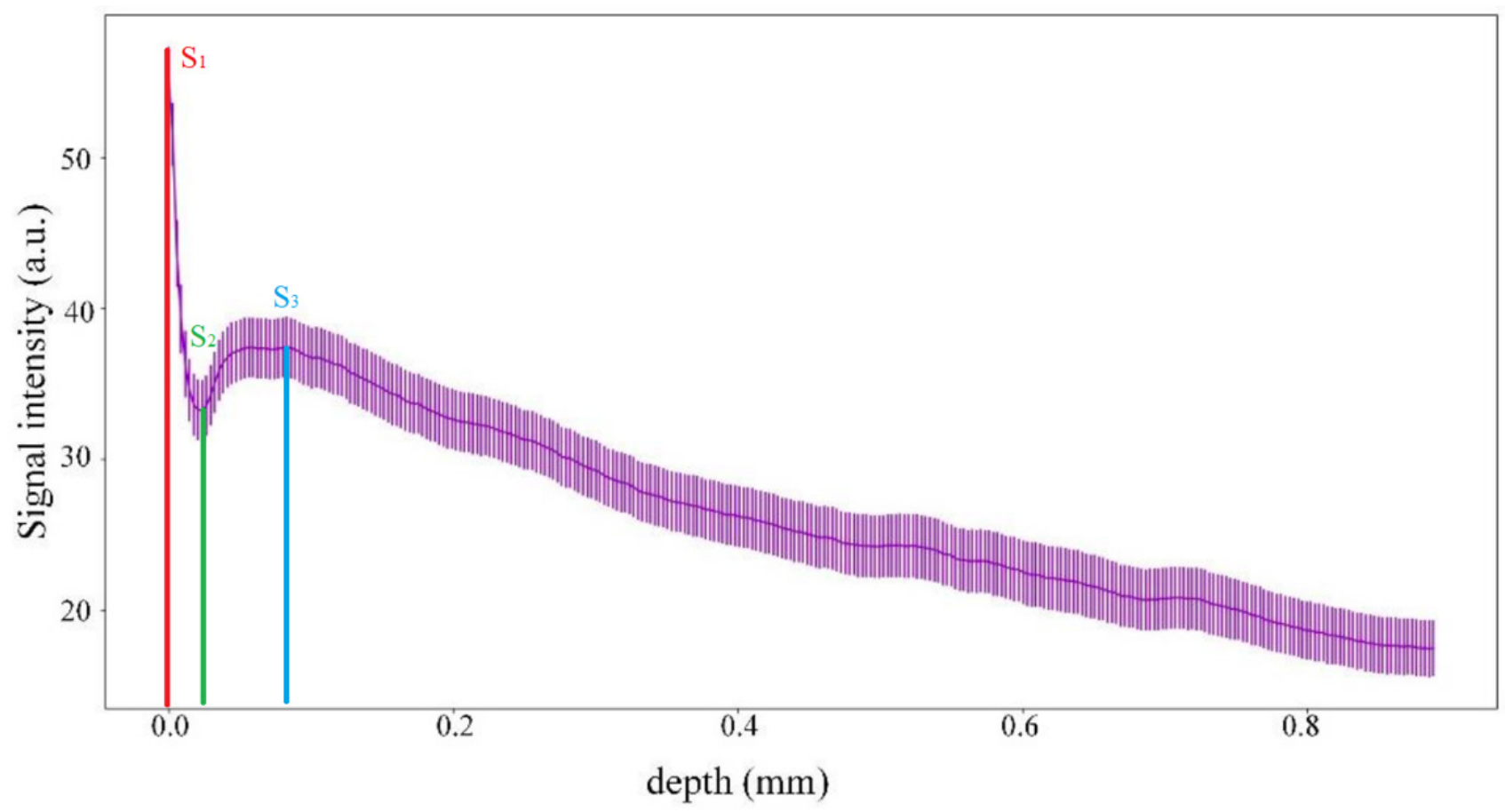

Figure 4. Dependence of signal intensity on depth for healthy skin: $S_{1}$ start point of the stratum corneum; $S_{2}$ 一the endpoint of epidermis; $S_{3}$-start point of the dermis. 
Day 1

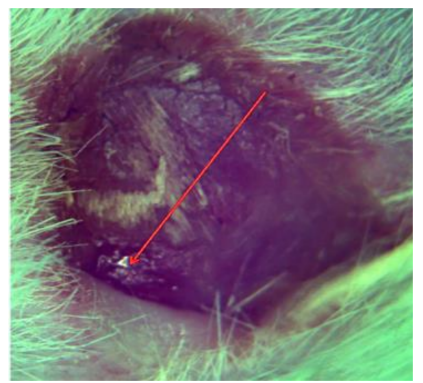

(a)

(b)

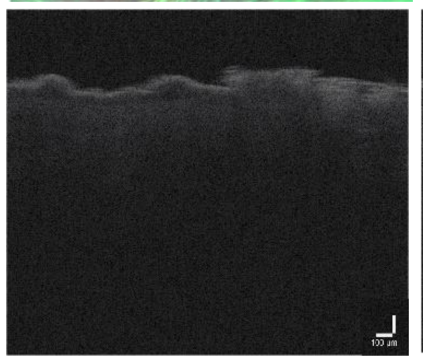

Day 3
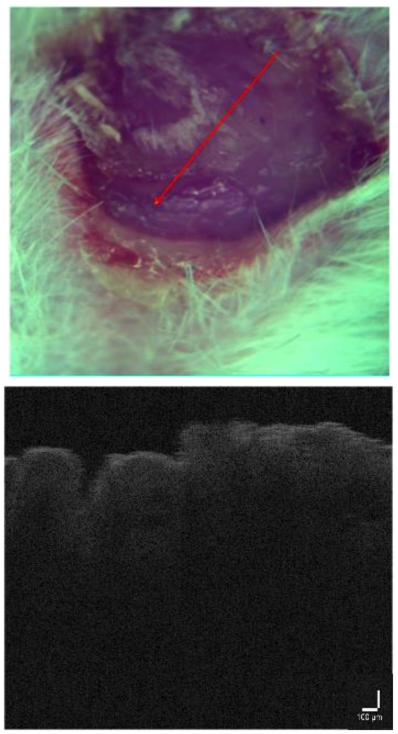

Day 7
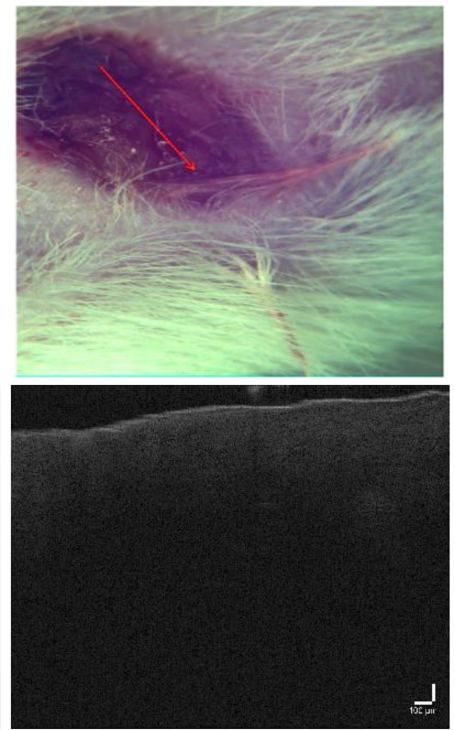

Day 14
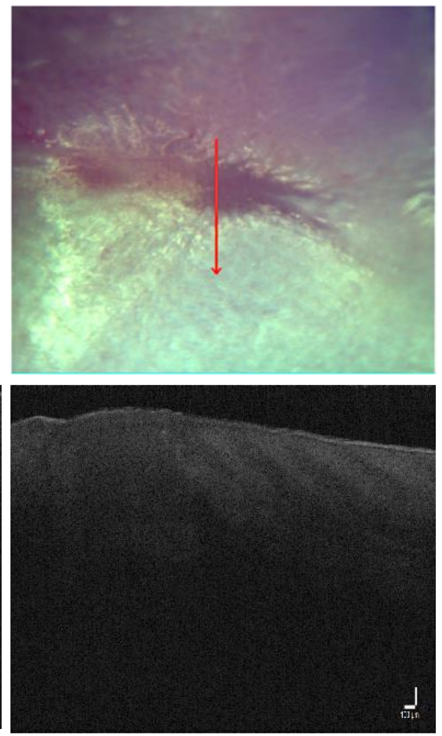

Figure 5. (a) Visual observation and (b) the corresponding B-scans for the control group.

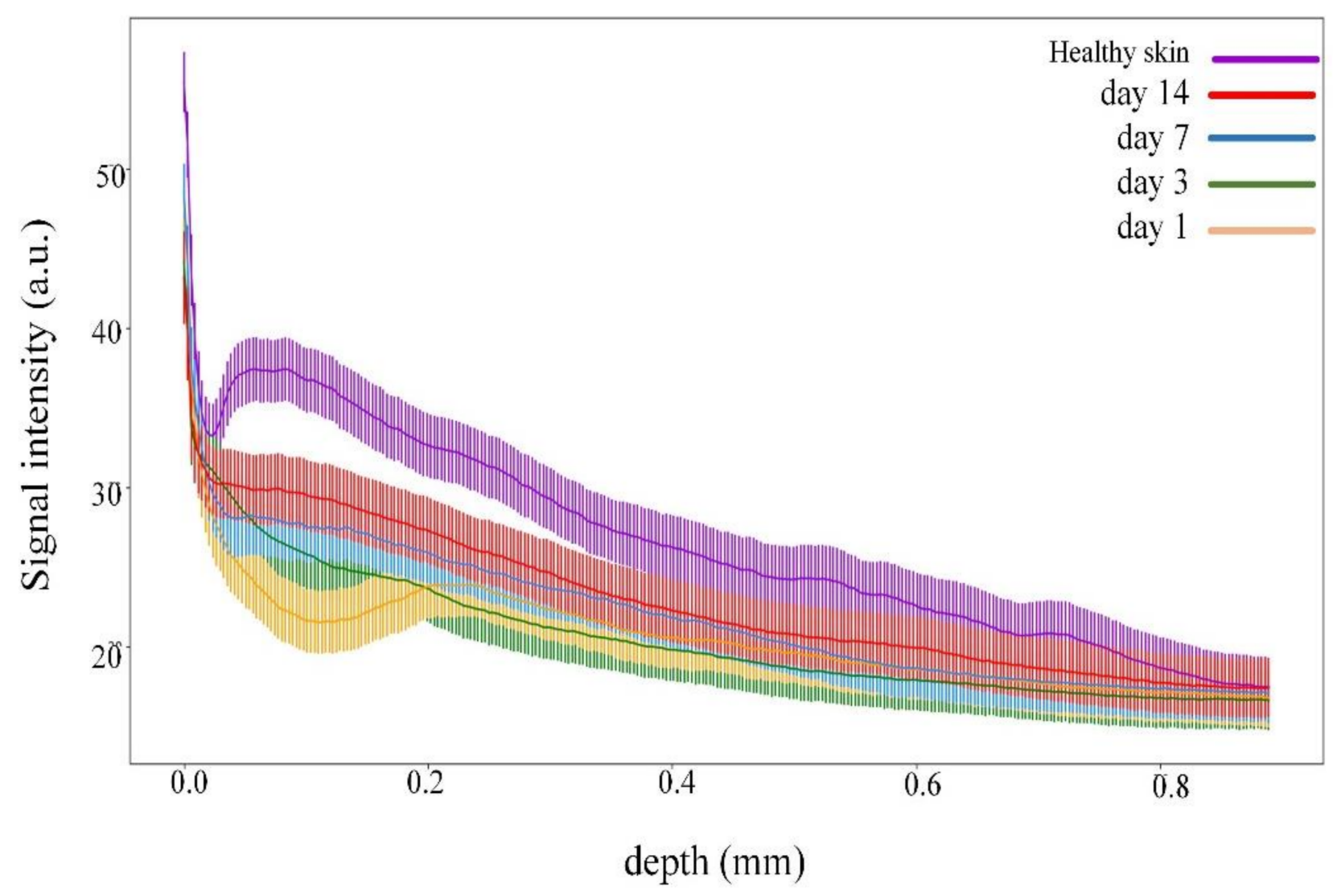

Figure 6. Dependence of signal intensity on depth for the control group during wound healing. 


\section{Day 1}

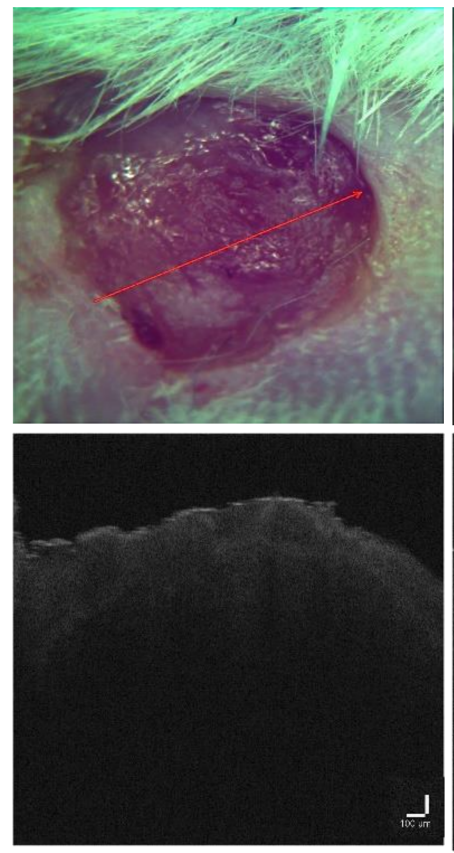

Day 3

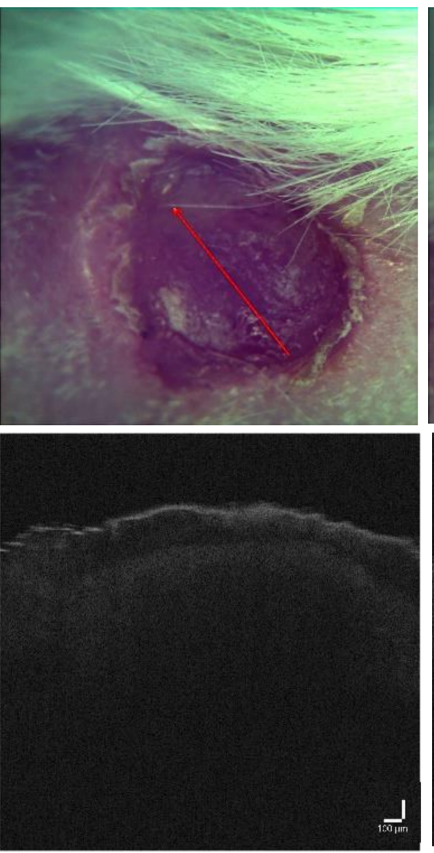

Day 7

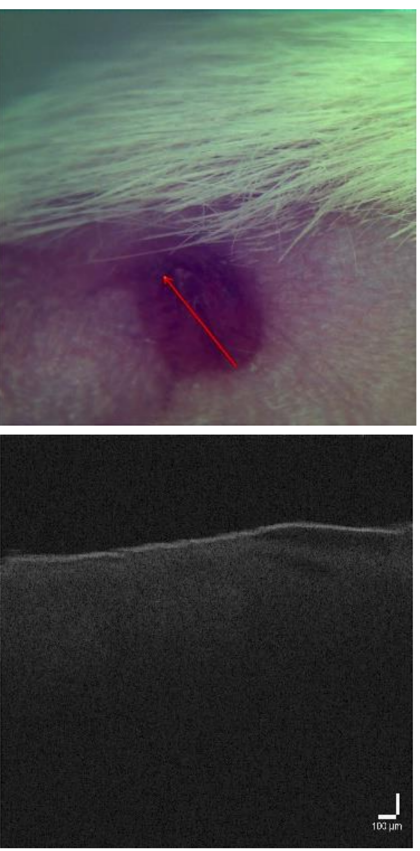

Day 14

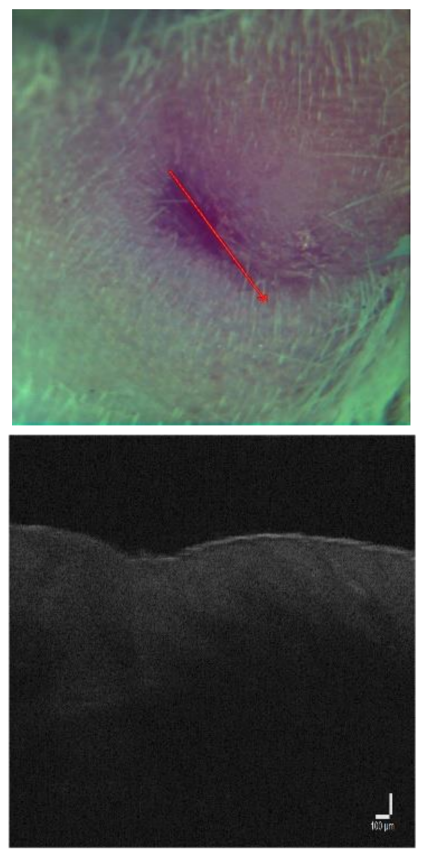

Figure 7. (a) Visual observation and (b) the corresponding B-scans for the LDPDT-5-ALA $1 \mathrm{~J} / \mathrm{cm}^{2}$ group.

Day 1

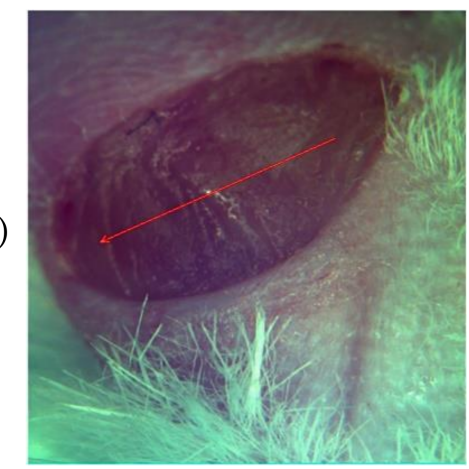

Day 3

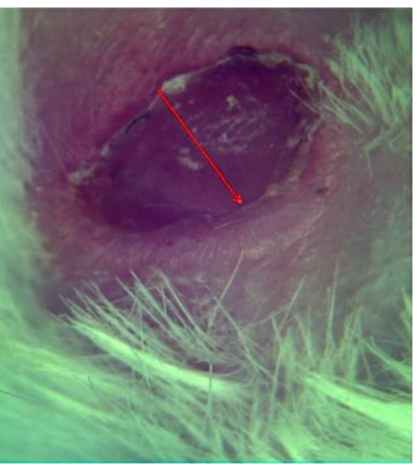

Day 7

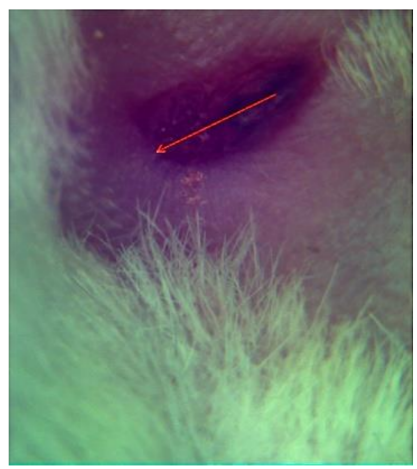

Day 14
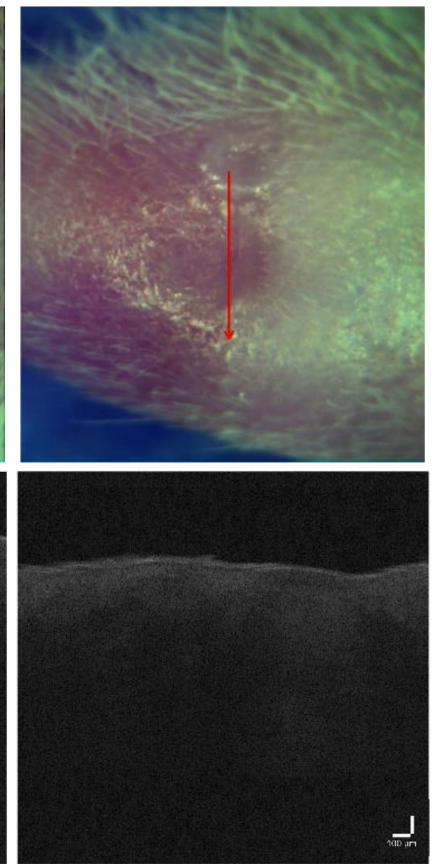

(b)
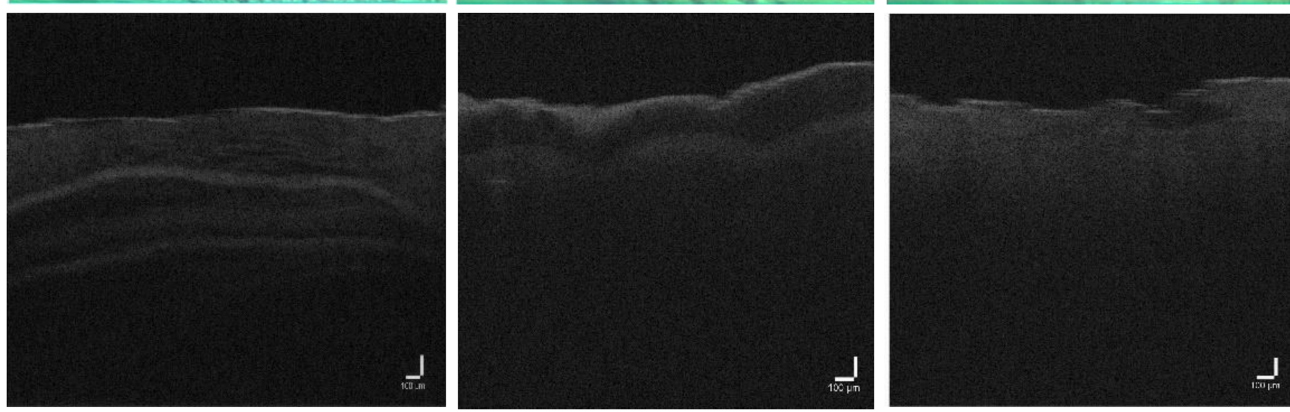

1

Figure 8. (a) Visual observation and (b) the corresponding B-scans for the LDPDT-5-ALA $4 \mathrm{~J} / \mathrm{cm}^{2}$ group. 


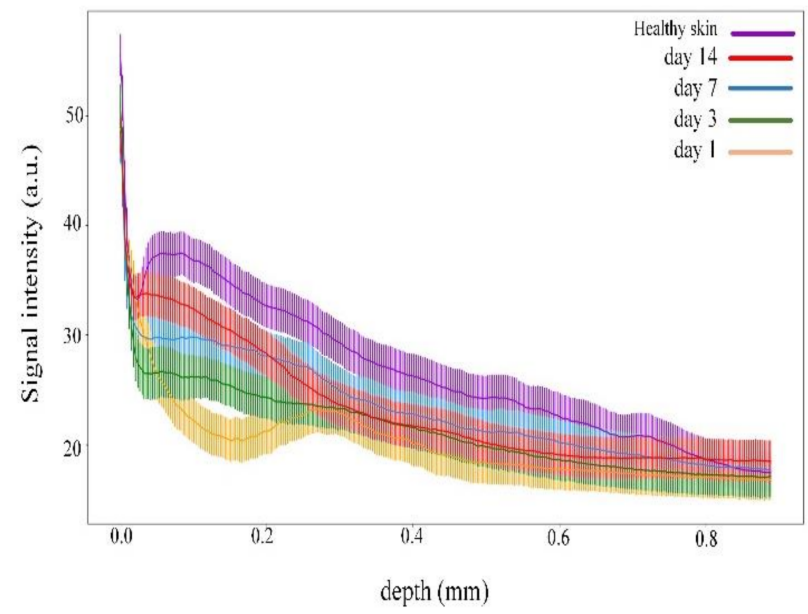

(a)

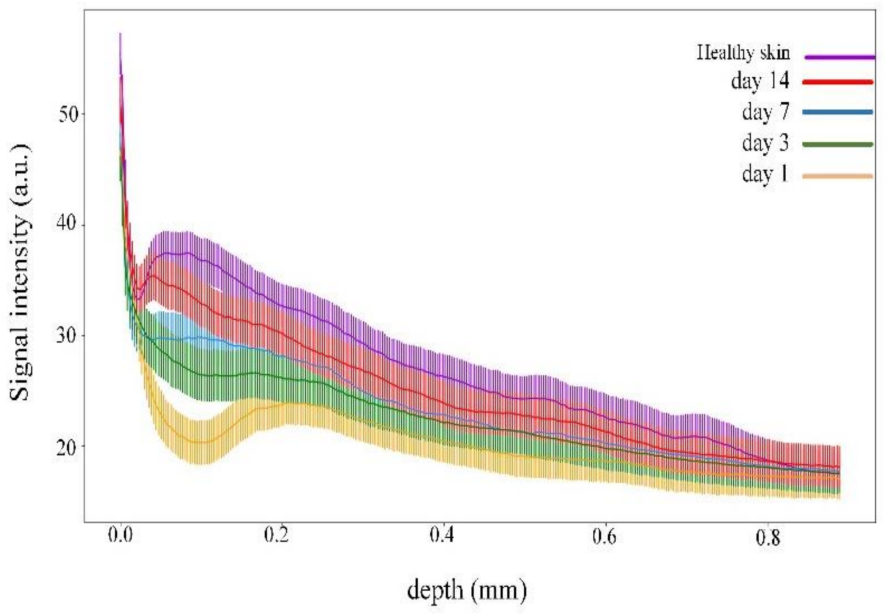

(b)

Figure 9. Dependence of signal intensity on depth for the (a) LDPDT-5-ALA $1 \mathrm{~J} / \mathrm{cm}^{2}$ group and (b) LDPDT-5-ALA $4 \mathrm{~J} / \mathrm{cm}^{2}$ group.

Day 1
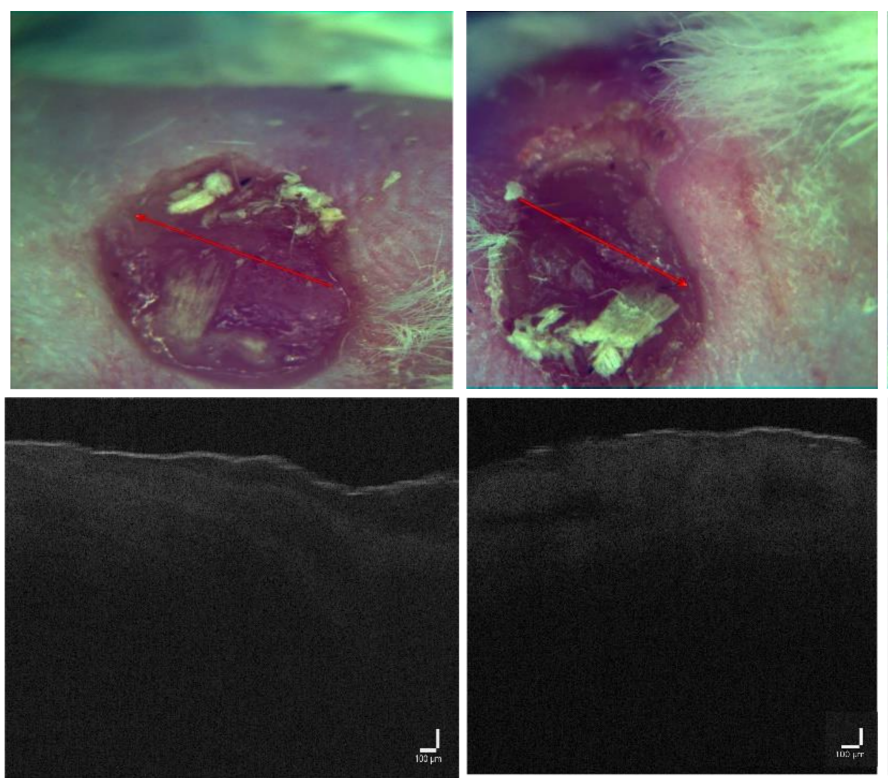

Day 7
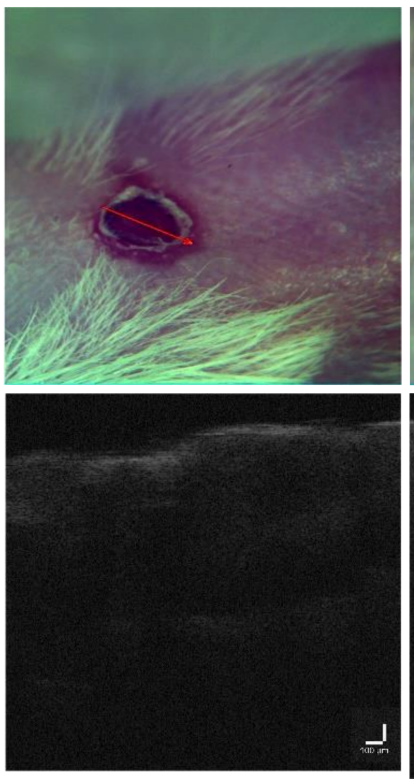

Day 14
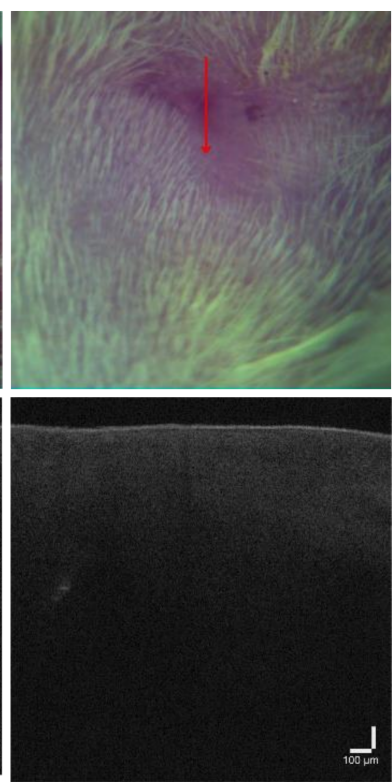

Figure 10. (a) Visual observation and (b) the corresponding B-scans for the LDPDT-MB $1 \mathrm{~J} / \mathrm{cm}^{2}$ group. 
Day 1

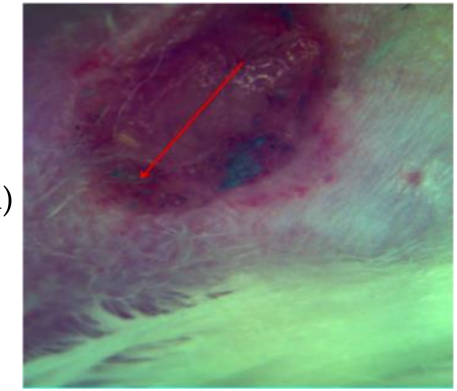

(a)

(b)

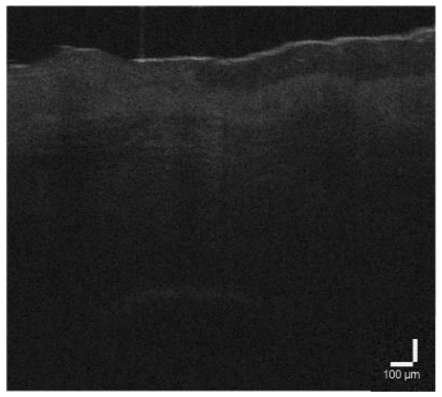

Day 3
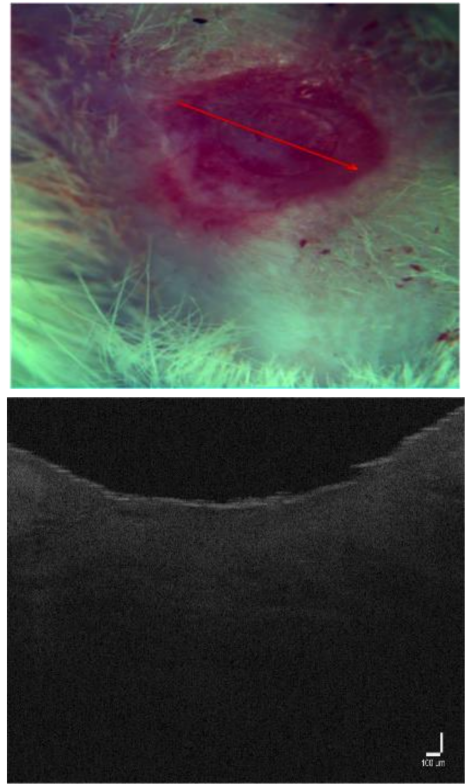

Day 7
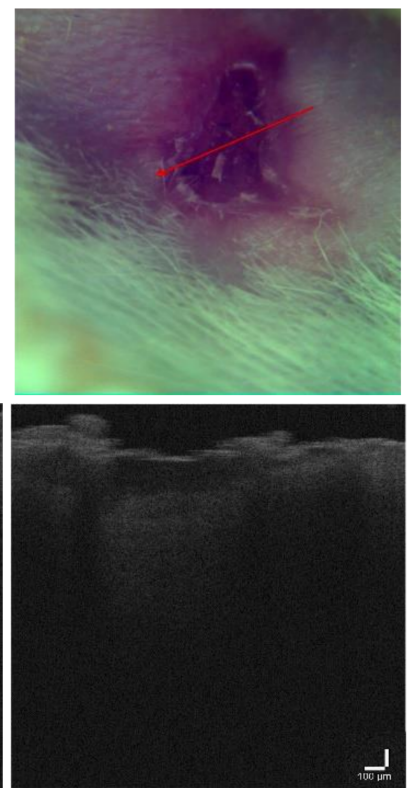

Day 14
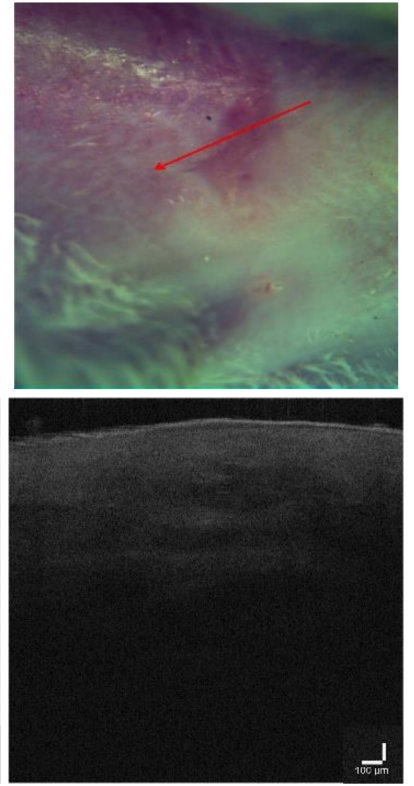

Figure 11. (a) Visual observation and (b) the corresponding B-scans for the LDPDT-MB $4 \mathrm{~J} / \mathrm{cm}^{2}$ group.

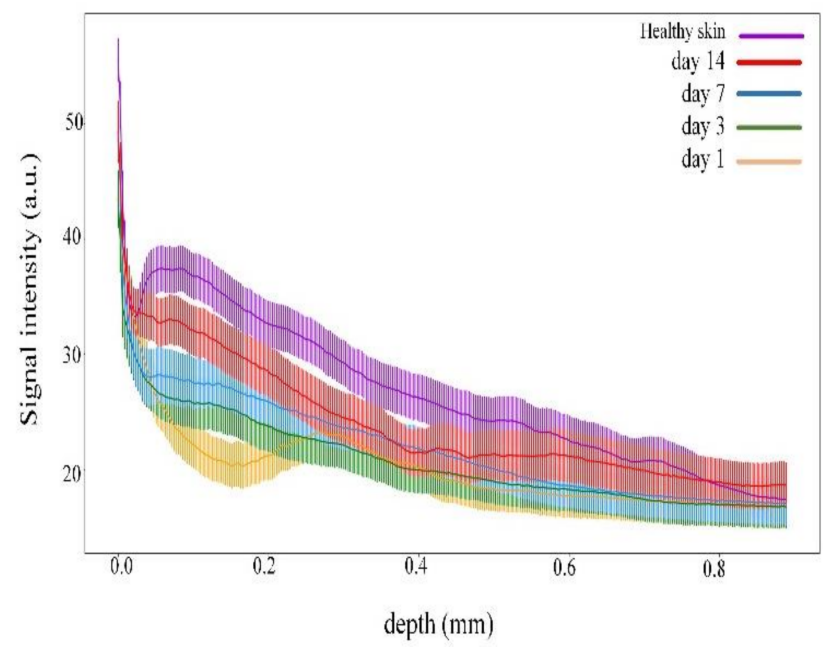

(a)

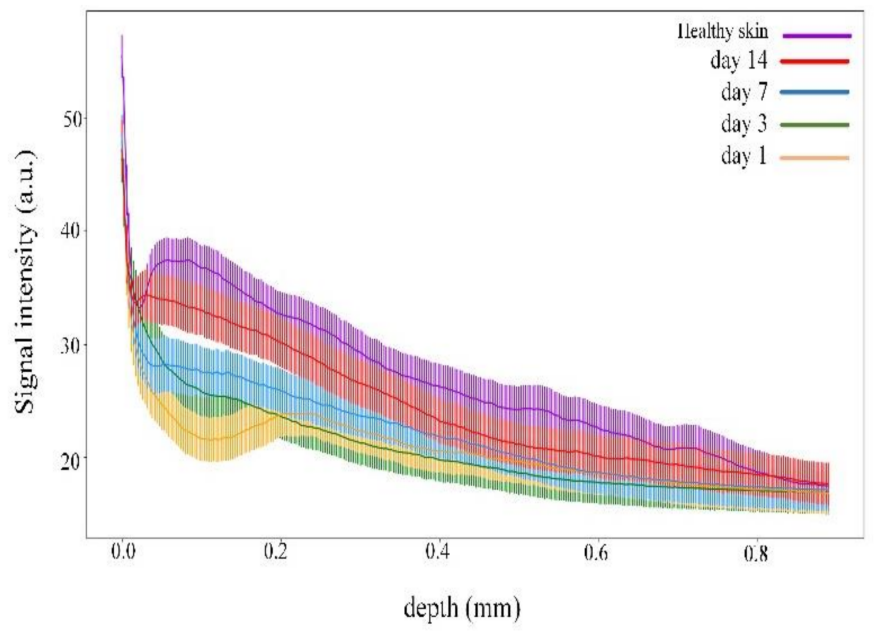

(b)

Figure 12. Dependence of signal intensity on depth for the (a) LDPDT-MB $1 \mathrm{~J} / \mathrm{cm}^{2}$ group and (b) LDPDT-MB $4 \mathrm{~J} / \mathrm{cm}^{2}$ group.

\subsection{Quantitative Comparison of the Spatial Proximity of the OCT Signal Intensity}

For a quantitative comparison of spatial profiles, we used the curve proximity factor (CPF) $S$, similar to the Pearson's correlation coefficient, to compare healthy skin and wound curves in all days to all groups [47]:

$$
S=\frac{\sum_{i}\left|X_{i}-Y_{i}\right|}{\frac{1}{2} \sum_{i}\left|X_{i}+Y_{i}\right|},
$$

where $X_{i}, Y_{i}$ is the intensity of the OCT signal for a definite depth from the wound and healthy skin, respectively. The higher the CPF value, the closer the wound state to healthy skin. The 0.01 and 0.05 significance levels were used to assess the statistical differences between the wound and healthy skin groups. The CPF values for all groups are shown in Table 1. 
Table 1. CPF values for the studied groups (mean \pm standard deviation).

\begin{tabular}{|c|c|c|c|c|c|}
\hline$n=5$ & Control & $\begin{array}{c}\text { LDPDT-5-ALA } \\
1 \mathrm{~J} / \mathrm{cm}^{2}\end{array}$ & $\begin{array}{c}\text { LDPDT-5-ALA } \\
4 \mathrm{~J} / \mathrm{cm}^{2}\end{array}$ & $\begin{array}{c}\text { LDPDT-MB } \\
1 \mathrm{~J} / \mathrm{cm}^{2}\end{array}$ & $\begin{array}{c}\text { LDPDT-MB } \\
4 \mathrm{~J} / \mathrm{cm}^{2}\end{array}$ \\
\hline Day 1 & $(0.0528 \pm 0.0084)^{* *}$ & $(0.0516 \pm 0.0072) * *$ & $(0.0517 \pm 0.0045) * *$ & $(0.0494 \pm 0.0083)^{* *}$ & $(0.0539 \pm 0.0064)^{* * *}$ \\
\hline Day 3 & $(0.0404 \pm 0.0141)^{* *}$ & $(0.0504 \pm 0.0106) *$ & $(0.0480 \pm 0.0087)^{* *}$ & $(0.0456 \pm 0.0169) *$ & $(0.0423 \pm 0.0134) *$ \\
\hline Day 7 & $(0.0316 \pm 0.0089) *$ & $(0.0379 \pm 0.0124) *$ & $(0.0315 \pm 0.0111) *$ & $(0.0361 \pm 0.0084) *$ & $(0.0305 \pm 0.0073)$ * \\
\hline Day 14 & $(0.0214 \pm 0.0076)$ * & $(0.0213 \pm 0.0075)$ & $(0.0187 \pm 0.0213)$ & $(0.0201 \pm 0.0054)$ & $(0.0174 \pm 0.0051)$ \\
\hline
\end{tabular}

${ }^{*} p>0.01, * * p>0.05$.

The CPF (1) was also used to estimate the effectiveness of different laser doses for each photosensitizer on day 14 . The CPF values calculated for the OCT signal intensity curves corresponding to $4 \mathrm{~J} / \mathrm{cm}^{2}$ and $1 \mathrm{~J} / \mathrm{cm}^{2}$ for 5-ALA (Figure 9) and MB (Figure 12) are shown in Table 2. These quantitative estimations demonstrated a "proximity" between the curves corresponding to $4 \mathrm{~J} / \mathrm{cm}^{2}$ laser dose and the curves corresponding to the $1 \mathrm{~J} / \mathrm{cm}^{2}$ laser dose for the same photosensitizer.

Table 2. CPF values for the studied groups (mean \pm standard deviation).

\begin{tabular}{ccc}
\hline $\boldsymbol{n}=\mathbf{5}$ & LDPDT-5-ALA & LDPDT-MB \\
\hline Day 14 & $(0.0115 \pm 0.0019) * *$ & $(0.0142 \pm 0.0011) *$ \\
\hline${ }^{*} p>0.005, * * p>0.01$. & &
\end{tabular}

\section{Discussion}

The proposed method of wound state quantitative evaluation is based on the OCT visualization of tissue structure transformation. The averaged scatter A-line intensity profile obtained from the horizontal rectangle in the OCT B-scan image of healthy skin is shown in Figure 4. Three areas are highlighted in the figure, representing changes in the attenuation coefficient. The red $\left(\mathrm{S}_{1}\right)$, green $\left(\mathrm{S}_{2}\right)$, and blue $\left(\mathrm{S}_{3}\right)$ lines correspond to the beginning of the stratum corneum, the end of the epidermis, and the beginning of the dermis, respectively. After inflicting a wound in the first days, there are no surface layers of the skin (horny, epidermis); instead, a scab forms on the surface. These changes in the skin are visible on A-scans. Over time, the skin recovers, and on A-scans, we can see the appearance of areas characteristic of the epidermis's end and the dermis's beginning. These changes are reflected in the OCT signal attenuation curve (see Figures 6, 8, 9 and 12).

For wound state quantitative estimation, we used the curve proximity factor, introduced by us earlier [47]. According to Table 1, in the control group, the CPF mean value on day 1 was about 0.053 , and decreased to 0.021 on day 14 , while in the LDPDT groups, the mean values of this coefficient on day 14 ranged from 0.017 to 0.021 . The Pearson test demonstrated that for LDPDT groups on day 14, $p$-value did not exceed 0.01 , while for the control group, this value was equal to 0.03 . Therefore, for all LPDT groups, the wound state had no statistically significant difference compared to healthy skin for the used statistical power levels.

The CPF value for LDPDT groups for the $4 \mathrm{~J} / \mathrm{cm}^{2}$ laser dose was smaller than the LDPDT groups for $1 \mathrm{~J} / \mathrm{cm}^{2}$. We also calculated the CPF values for the OCT signal intensity curves corresponding to $4 \mathrm{~J} / \mathrm{cm}^{2}$ and $1 \mathrm{~J} / \mathrm{cm}^{2}$ for 5-ALA (the first column in Table 1) and MB (the second column in Table 2) and conducted a Pearson test to check the statistical significance of these differences. $p$-value was shown to be larger for 5-ALA.

Therefore, after comparing the CPF parameter for five groups: control, LDPDT 5-ALA $4 \mathrm{~J} / \mathrm{cm}^{2}$, LDPDT 5-ALA $1 \mathrm{~J} / \mathrm{cm}^{2}$, LDPDT-MB $4 \mathrm{~J} / \mathrm{cm}^{2}$, and LDPDT-MB $1 \mathrm{~J} / \mathrm{cm}^{2}$, it was concluded that the laser dose of $4 \mathrm{~J} / \mathrm{cm}^{2}$ for LDPDT 5-ALA was definitely better compared to $1 \mathrm{~J} / \mathrm{cm}^{2}$ and probably better for LDPDT MB. It should be noted that the conclusion depends on the volume and quality of the dataset.

A possible reason for the $4 \mathrm{~J} / \mathrm{cm}^{2}$ dose preference relative to the $1 \mathrm{~J} / \mathrm{cm}^{2}$ dose is as follows. According to previous works [33-35], when low-level laser light is applied and a 
dose is too low, no tissue response will occur. If too a high dose is applied, it can inhibit a tissue response. It has been seen in studies of wound healing where too low a dose did not have an impact, and too high a dose (above $5 \mathrm{~J} / \mathrm{cm}^{2}$ ) prolonged wound healing while the optimal dose resulted in faster healing. In this interval, according to the Arndt-Schultz curve, the larger dose causes a stronger biological effect.

In any case, LDPDT allows for accelerating of the wound healing process, which is consistent with the literature data [32-34,48,49].

\section{Conclusions}

In this paper, a study of quantitative in vivo evaluation of wounds using OCT during the wound healing process was carried out. 5-ALA and MB were used as photosensitizers for LDPDT, with two laser doses of 1 and $4 \mathrm{~J} / \mathrm{cm}^{2}$.

An approach to quantitative estimation of wound state based on the CPF, Equation (1) [47] was proposed. The method was used to quantify the effectiveness of LDPDT to accelerate the wound healing process. CPF parameter estimation allowed us to compare LDPDT regimes quantitatively and to obtain objective arguments about the superiority of one regime over another.

Therefore, the proposed CPF parameter, estimated from OCT data, has demonstrated its feasibility for the quantitative estimation of the human wound state during healing. This approach is noninvasive, simple in implementation, and suitable for continuous monitoring throughout the wound healing process and sufficient resolution to assess both anatomy and pathology. It makes it a promising technique for applications in wound healing and the evaluation of novel therapeutics.

Another approach, which was proven to be effective in monitoring wound healing is two-photon microscopy. Previously, our group analyzed the two-photon microscopy images of the wound healing process and succeeded in quantitatively assessing the state of the wound and studying the effect of low-dose photodynamic therapy using the techniques of two-photon microscopy. The results of this study are completely consistent with the results obtained earlier [50].

Author Contributions: Conceptualization, Y.V.K.; Methodology, H.Z. and E.A.S.; Software, V.V.N.; Validation, H.Z. and V.V.N.; Investigation, H.Z., V.V.N., T.B.L. and N.A.K.; Writing-original draft preparation, E.A.S.; Writing-review and editing, Y.V.K.; Visualization, H.Z.; Supervision, Y.V.K. All authors have read and agreed to the published version of the manuscript.

Funding: This research was funded by a grant under the Decree of the Government of the Russian Federation No. 220 of 9 April 2010 (Agreement No. 075-15-2021-615 of 4 June 2021).

Institutional Review Board Statement: The study was approved by the Ethics Committee of Tomsk State University (Protocol No.4, 10.02.2021), registration No. 6.

Data Availability Statement: The data presented in this study are available on request from the corresponding author.

Conflicts of Interest: The authors declare no conflict of interest.

\section{References}

1. World Health Organization. Burns. Available online: https://www.who.int/news-room/fact-sheets/detail/burns (accessed on 15 December 2021).

2. Nussbaum, S.R.; Carter, M.J.; Fife, C.E.; DaVanzo, J.; Haught, R.; Nusgart, M.; Cartwright, D. An Economic Evaluation of the Impact, Cost, and Medicare Policy Implications of Chronic Nonhealing Wounds. Value Health 2018, 21, 27-32. [CrossRef] [PubMed]

3. De Gonzalez, A.C.O.; Costa, T.F.; de Andrade, Z.A.; Medrado, A.R.A.P. Wound Healing-A Literature Review. An. Bras. Dermatol. 2016, 91, 614-620. [CrossRef] [PubMed]

4. Sorg, H.; Tilkorn, D.J.; Hager, S.; Hauser, J.; Mirastschijski, U. Skin Wound Healing: An Update on the Current Knowledge and Concepts. Eur. Surg. Res. 2017, 58, 81-94. [CrossRef] [PubMed] 
5. Liu, H.; Liu, H.; Deng, X.; Chen, M.; Han, X.; Yan, W.; Wang, N. Raman Spectroscopy Combined with SHG Gives a New Perspective for Rapid Assessment of the Collagen Status in the Healing of Cutaneous Wounds. Anal. Methods 2016, 8, 3503-3510. [CrossRef]

6. Mickelson, M.A.; Mans, C.; Colopy, S.A. Principles of Wound Management and Wound Healing in Exotic Pets. Vet. Clin. N. Am. Exot. Anim. Pract. 2016, 19, 33-53. [CrossRef] [PubMed]

7. Deka, G.; Wu, W.-W.; Kao, F.-J. In Vivo Wound Healing Diagnosis with Second Harmonic and Fluorescence Lifetime Imaging. J. Biomed. Opt. 2012, 18, 061222. [CrossRef]

8. Zuhayri, H.; Knyazkova, A.I.; Nikolaev, V.V.; Borisov, A.V.; Kistenev, Y.V.; Zakharova, O.A.; Dyachenko, P.A.; Tuchin, V.V. Study of Wound Healing by Terahertz Spectroscopy. Proceedings of the Fourth International Conference on Terahertz and Microwave Radiation: Generation, Detection, and Applications; Romanovskii, Tomsk, Russia, 24-26 August 2020; Zakharova, O.A., Kistenev, Y.V., Eds.; SPIE: Tomsk, Russia, 2020; p. 63.

9. Bolton, L. Peripheral Arterial Disease: Scoping Review of Patient-centred Outcomes. Int. Wound J. 2019, 16, 1521-1532. [CrossRef] [PubMed]

10. Baltzis, D.; Eleftheriadou, I.; Veves, A. Pathogenesis and Treatment of Impaired Wound Healing in Diabetes Mellitus: New Insights. Adv. Ther. 2014, 31, 817-836. [CrossRef] [PubMed]

11. Mazumder, N.; Ball, K.N.; Zhuo, K.-Q.; Kistenev, Y.V.; Kumar, R.; Kao, F.-J.; Brasselet, S.; Nikolaev, V.V.; Krivova, N.A. Label-Free Multimodal Nonlinear Optical Microscopy for Biomedical Applications. J. Appl. Phys. 2021, 129, 214901. [CrossRef]

12. Phillips, C.J.; Humphreys, I.; Fletcher, J.; Harding, K.; Chamberlain, G.; Macey, S. Estimating the Costs Associated with the Management of Patients with Chronic Wounds Using Linked Routine Data: Costs of Wounds Using Routine Data. Int. Wound J. 2016, 13, 1193-1197. [CrossRef]

13. Guest, J.F.; Ayoub, N.; McIlwraith, T.; Uchegbu, I.; Gerrish, A.; Weidlich, D.; Vowden, K.; Vowden, P. Health Economic Burden That Wounds Impose on the National Health Service in the UK. BMJ Open 2015, 5, e009283. [CrossRef]

14. Heyer, K.; Herberger, K.; Protz, K.; Glaeske, G.; Augustin, M. Epidemiology of Chronic Wounds in Germany: Analysis of Statutory Health Insurance Data: Epidemiology of Chronic Wounds in Germany. Wound Rep. Reg. 2016, 24, 434-442. [CrossRef] [PubMed]

15. Tedesco, A.; Jesus, P. Low Level Energy Photodynamic Therapy for Skin Processes and Regeneration. In Photomedicine-Advances in Clinical Practice; Tanaka, Y., Ed.; InTech: London, UK, 2017; ISBN 978-953-51-3155-7.

16. Shaw, T.J.; Martin, P. Wound Repair at a Glance. J. Cell Sci. 2009, 122, 3209-3213. [CrossRef] [PubMed]

17. Yang, T.; Tan, Y.; Zhang, W.; Yang, W.; Luo, J.; Chen, L.; Liu, H.; Yang, G.; Lei, X. Effects of ALA-PDT on the Healing of Mouse Skin Wounds Infected With Pseudomonas Aeruginosa and Its Related Mechanisms. Front. Cell Dev. Biol. 2020, 8, 585132. [CrossRef]

18. Algorri, J.F.; Ochoa, M.; Roldán-Varona, P.; Rodríguez-Cobo, L.; López-Higuera, J.M. Photodynamic Therapy: A Compendium of Latest Reviews. Cancers 2021, 13, 4447. [CrossRef] [PubMed]

19. Kwiatkowski, S.; Knap, B.; Przystupski, D.; Saczko, J.; Kędzierska, E.; Knap-Czop, K.; Kotlińska, J.; Michel, O.; Kotowski, K.; Kulbacka, J. Photodynamic Therapy-Mechanisms, Photosensitizers and Combinations. Biomed. PharmacoTher. 2018, 106, 1098-1107. [CrossRef] [PubMed]

20. Peplow, P.V.; Chung, T.-Y.; Baxter, G.D. Photodynamic Modulation of Wound Healing: A Review of Human and Animal Studies. Photomed. Laser Surg. 2012, 30, 118-148. [CrossRef]

21. Vallejo, M.C.S.; Moura, N.M.M.; Ferreira Faustino, M.A.; Almeida, A.; Gonçalves, I.; Serra, V.V.; Neves, M.G.P.M.S. An Insight into the Role of Non-Porphyrinoid Photosensitizers for Skin Wound Healing. IJMS 2020, 22, 234. [CrossRef]

22. Morimoto, K.; Ozawa, T.; Awazu, K.; Ito, N.; Honda, N.; Matsumoto, S.; Tsuruta, D. Photodynamic Therapy Using Systemic Administration of 5-Aminolevulinic Acid and a 410-Nm Wavelength Light-Emitting Diode for Methicillin-Resistant Staphylococcus Aureus-Infected Ulcers in Mice. PLoS ONE 2014, 9, e105173. [CrossRef]

23. Yin, R.; Lin, L.; Xiao, Y.; Hao, F.; Hamblin, M.R. Combination ALA-PDT and Ablative Fractional Er:YAG Laser (2,940 Nm) on the Treatment of Severe Acne: Combination ala-pdt and ablative fractional er:yag laser. Lasers Surg. Med. 2014, 46, 165-172. [CrossRef]

24. Jiang, C.; Yang, W.; Wang, C.; Qin, W.; Ming, J.; Zhang, M.; Qian, H.; Jiao, T. Methylene Blue-Mediated Photodynamic Therapy Induces Macrophage Apoptosis via ROS and Reduces Bone Resorption in Periodontitis. Oxid. Med. Cell. Longev. 2019, $2019,1-15$. [CrossRef] [PubMed]

25. Sperandio, F.F.; Simões, A.; Aranha, A.C.C.; Corrêa, L.; Orsini Machado de Sousa, S.C. Photodynamic Therapy Mediated by Methylene Blue Dye in Wound Healing. Photomed. Laser Surg. 2010, 28, 581-587. [CrossRef] [PubMed]

26. Pérez, M.; Robres, P.; Moreno, B.; Bolea, R.; Verde, M.T.; Pérez-Laguna, V.; Aspiroz, C.; Gilaberte, Y.; Rezusta, A. Comparison of Antibacterial Activity and Wound Healing in a Superficial Abrasion Mouse Model of Staphylococcus Aureus Skin Infection Using Photodynamic Therapy Based on Methylene Blue or Mupirocin or Both. Front. Med. 2021, 8, 673408. [CrossRef] [PubMed]

27. Carneiro, V.S.M.; de Catao, M.H.C.V.; Menezes, R.F.; Araújo, N.C.; Gerbi, M.E.M. Methylene Blue Photodynamic Therapy in Rats Wound Healing: 21 Days Follow-Up; Kurachi, C., Svanberg, K., Tromberg, B.J., Bagnato, V.S., Eds.; SPIE Proceedings: Rio de Janeiro, Brazil, 2015; p. 95311S.

28. Xiong, Z.-M.; O’Donovan, M.; Sun, L.; Choi, J.Y.; Ren, M.; Cao, K. Anti-Aging Potentials of Methylene Blue for Human Skin Longevity. Sci. Rep. 2017, 7, 2475. [CrossRef]

29. Yang, Z.; Hu, X.; Zhou, L.; He, Y.; Zhang, X.; Yang, J.; Ju, Z.; Liou, Y.-C.; Shen, H.-M.; Luo, G.; et al. Photodynamic Therapy Accelerates Skin Wound Healing through Promoting Re-Epithelialization. Burn. Trauma 2021, 9, tkab008. [CrossRef] [PubMed] 
30. Huang, Y.-Y.; Chen, A.C.-H.; Carroll, J.D.; Hamblin, M.R. Biphasic Dose Response in Low Level Light Therapy. Dose-Resp. 2009, 7, 358-383. [CrossRef] [PubMed]

31. Huang, Y.-Y.; Sharma, S.K.; Carroll, J.; Hamblin, M.R. Biphasic Dose Response in Low Level Light Therapy—an Update. Dose-Resp. 2011, 9, 602-618. [CrossRef] [PubMed]

32. Hawkins, D.H.; Abrahamse, H. The Role of Laser Fluence in Cell Viability, Proliferation, and Membrane Integrity of Wounded Human Skin Fibroblasts Following Helium-Neon Laser Irradiation. Lasers Surg. Med. 2006, 38, 74-83. [CrossRef] [PubMed]

33. Byrnes, K.R.; Barna, L.; Chenault, V.M.; Waynant, R.W.; Ilev, I.K.; Longo, L.; Miracco, C.; Johnson, B.; Anders, J.J. Photobiomodulation Improves Cutaneous Wound Healing in an Animal Model of Type II Diabetes. Photomed. Laser Surg. 2004, 22, $281-290$. [CrossRef] [PubMed]

34. Prabhu, V.; Rao, S.B.S.; Chandra, S.; Kumar, P.; Rao, L.; Guddattu, V.; Satyamoorthy, K.; Mahato, K.K. Spectroscopic and Histological Evaluation of Wound Healing Progression Following Low Level Laser Therapy (LLLT). J. Biophoton. 2012, 5, 168-184. [CrossRef] [PubMed]

35. Basso, F.G.; Pansani, T.N.; Turrioni, A.P.S.; Bagnato, V.S.; Hebling, J.; de Souza Costa, C.A. In Vitro Wound Healing Improvement by Low-Level Laser Therapy Application in Cultured Gingival Fibroblasts. Int. J. Dent. 2012, 2012, 1-6. [CrossRef] [PubMed]

36. De Chaves, M.E.A.; de Araújo, A.R.; Piancastelli, A.C.C.; Pinotti, M. Effects of Low-Power Light Therapy on Wound Healing: LASER x LED. An. Bras. Dermatol. 2014, 89, 616-623. [CrossRef] [PubMed]

37. Monstrey, S.; Hoeksema, H.; Verbelen, J.; Pirayesh, A.; Blondeel, P. Assessment of Burn Depth and Burn Wound Healing Potential. Burns 2008, 34, 761-769. [CrossRef] [PubMed]

38. Huang, D.; Swanson, E.A.; Lin, C.P.; Schuman, J.S.; Stinson, W.G.; Chang, W.; Hee, M.R.; Flotte, T.; Gregory, K.; Puliafito, C.A.; et al Optical Coherence Tomography. Science 1991, 254, 1178-1181. [CrossRef]

39. Almasian, M.; Bosschaart, N.; van Leeuwen, T.G.; Faber, D.J. Validation of Quantitative Attenuation and Backscattering Coefficient Measurements by Optical Coherence Tomography in the Concentration-Dependent and Multiple Scattering Regime. J. Biomed. Opt. 2015, 20, 121314. [CrossRef] [PubMed]

40. Evans, N.D.; Oreffo, R.O.C.; Healy, E.; Thurner, P.J.; Man, Y.H. Epithelial Mechanobiology, Skin Wound Healing, and the Stem Cell Niche. J. Mech. Behav. Biomed. Mater. 2013, 28, 397-409. [CrossRef] [PubMed]

41. Tan, S.T.; Dosan, R. Lessons From Epithelialization: The Reason Behind Moist Wound Environment. TODJ 2019, 13, 34-40. [CrossRef]

42. Yuan, Z.; Zakhaleva, J.; Ren, H.; Liu, J.; Chen, W.; Pan, Y. Noninvasive and High-Resolution Optical Monitoring of Healing of Diabetic Dermal Excisional Wounds Implanted with Biodegradable In Situ Gelable Hydrogels. Tissue Eng. Part C: Methods 2010, 16, 237-247. [CrossRef] [PubMed]

43. Bulygin, A.D.; Vrazhnov, D.A.; Sim, E.S.; Meglinski, I.; Kistenev, Y.V. Imitation of Optical Coherence Tomography Images by Wave Monte Carlo-Based Approach Implemented with the Leontovich-Fock Equation. Opt. Eng. 2020, 59, 1. [CrossRef]

44. Kistenev, Y.; Buligin, A.D.; Sandykova, E.; Sim, E.; Vrazhnov, D. Optical Coherence Tomography Modeling Method Based on LeontovichFock Equation. Proceedings of the 25th International Symposium on Atmospheric and Ocean Optics: Atmospheric Physics; Matvienko, G.G., Romanovskii, O.A., Eds.; SPIE: Novosibirsk, Russia, 2019; p. 130.

45. Jaspers, M.E.H.; Feroldi, F.; Vlig, M.; de Boer, J.F.; van Zuijlen, P.P.M. In Vivo Polarization-Sensitive Optical Coherence Tomography of Human Burn Scars: Birefringence Quantification and Correspondence with Histologically Determined Collagen Density. J. Biomed. Opt. 2017, 22, 1. [CrossRef]

46. Chen, C.-L.; Wang, R.K. Optical Coherence Tomography Based Angiography [Invited]. Biomed. Opt. Expr. 2017, 8, 1056. [CrossRef] [PubMed]

47. Kistenev, Y.V.; Kuzmin, D.A.; Sandykova, E.A.; Shapovalov, A.V. Quantitative Comparison of the Absorption Spectra of the Gas Mixtures in Analogy to the Criterion of Pearson; Romanovskii, O.A., Ed.; SPIE Proceedings: Tomsk, Russia, 2015; p. 96803S.

48. Zein, R.; Selting, W.; Hamblin, M.R. Review of Light Parameters and Photobiomodulation Efficacy: Dive into Complexity. J. Biomed. Opt. 2018, 23, 1. [CrossRef] [PubMed]

49. Kilík, R.; Lakyová, L.; Sabo, J.; Kruzliak, P.; Lacjaková, K.; Vasilenko, T.; Vidová, M.; Longauer, F.; Radoňak, J. Effect of Equal Daily Doses Achieved by Different Power Densities of Low-Level Laser Therapy at $635 \mathrm{Nm}$ on Open Skin Wound Healing in Normal and Diabetic Rats. BioMed. Res. Int. 2014, 2014, 1-9. [CrossRef] [PubMed]

50. Zuhayri, H.; Nikolaev, V.V.; Knyazkova, A.I.; Lepekhina, T.B.; Krivova, N.A.; Tuchin, V.V.; Kistenev, Y.V. In Vivo Quantification of the Effectiveness of Topical Low-Dose Photodynamic Therapy in Wound Healing Using Two-Photon Microscopy. Pharmaceutics 2022, 14, 287. [CrossRef] 